\title{
O volume I da História da Inglaterra e o debate constitucional inglês: Hume contra a ideia de lei fundamental
}

\author{
Volume I of The History of England and the English constitutional \\ debate: Hume against the idea of fundamental law
}

Maria Isabel Limongi

belimongi@yahoo.com.br

(Universidade Federal do Paraná, Paraná Brasil)

\begin{abstract}
Resumo: No volume I da História da Inglaterra, Hume trata de três tópicos importantes da história inglesa em função do modo como foram interpretados e mobilizados pelos partidos em disputa nodebate constitucional inglês dos séculos XVII e XVIII. A partir da reconstrução da posição de Hume com relação a esses tópicos (a constituição saxã, a conquista normanda e a Magna Carta), pretende-se mostrar como Hume recusa a ideia de lei fundamental que esteve no centro desse debate, para ver emergir a partir daí a sua própria concepção da lei enquanto instituição social.
\end{abstract}

Palavras-chave: Hume; História da Inglaterra; lei fundamental

\begin{abstract}
In The History of England's first volume, Hume addresses three important topics in English history in terms of how they have been interpreted and mobilized by disputing parties in the English constitutional debate of the seventeenth and eighteenth centuries. By reconstructing Hume's position regarding these topics (the Saxon constitution, the Norman Conquest and the Magna Carta), I intend to show how Hume refuses the idea of fundamental law that was at the heart of this debate, where upon his own conception of law as a social institution emerges.
\end{abstract}

Keywords: Hume; History of England; fundamental law.

DOI: http://dx.doi.org/10.11606/issn.2318-9800.v20i2p37-65

Encontramos nos seis volumes da História da Inglaterra de Hume fundamentalmente uma história da lei e da constituição inglesa. Trata-se também de história econômica e da história dos costumes ou maneiras [manners], mas o fio condutor é a lei ou o processo de formação de um sistema legal como elemento de regulação das relações sociais.

Enquanto a história da lei, convém ler a História da Inglaterra em paralelo com a teoria da justiça ${ }^{1}$ desenvolvida no Tratado da Natureza Humana e na Investigação

1 Entenda-se: o que Hume escreveu sobre a justiça no Tratado e na Investigação. Em que sentido penso que Hume tem uma "teoria da justiça", no sentido de uma posição sobre o que devem ser os arranjos institucionais para que sejam justos, é uma longa discussão, que não cabe ser feita aqui. Para uma posição contrária, ver WEIN, S. David Hume and the empiricist theory of law. Man and 
sobre os Princípios da Moral, textos em que Hume pensa a justiça enquanto um conjunto de regras gerais (ou leis) reguladoras das relações de propriedade e de governo. $\mathrm{Na}$ esteira da tradição da lei natural inaugurada por Grotius, Hume entende que a lei natural se desenvolve numa história ${ }^{2}$. Resta a precisar a relação entre esta história da lei natural, elaborada no Tratado e na Investigação, e a história da lei elaborada na História da Inglaterra. Há quem pense não haver aí uma relação relevante ou que a História da Inglaterra seja só uma ilustração da teoria da justiça plenamente desenvolvida no Tratado (como Haarkonsen ${ }^{3}$ e todos aqueles que passaram ao largo da História da Inglaterra em suas interpretações da teoria da justiça de Hume); há quem pense, ao contrário, que os textos são complementares ${ }^{4}$ e quem pense, de outro modo, que Hume tenha alterado significativamente sua concepção da justiça na passagem do Tratado para a História ${ }^{5}$. Trata-se de uma questão controversa e ainda pouco trabalhada a da relação entre este conjunto de obras. Mas, sem causar muita polêmica, pode-se dizer que no Tratado Hume procura traçar as linhas gerais ou identificar as causas gerais que presidem a história da lei, enquanto que na História da Inglaterra trata-se de compreender a instituição da lei a partir das circunstâncias particulares da história inglesa.

$\mathrm{Na}$ atenção que dá às circunstâncias e particularidades da história inglesa a fim de reconstituir a história da lei, Hume é o herdeiro do intenso debate constitucional que se desenrolou na Inglaterra desde o período que precede à guerra civil inglesa - desde o reino de Jaime I - até o momento em que ele escreve, após a Revolução Gloriosa, quando então a constituição mista inglesa havia enfim se estabilizado, sem que contudo tivesse se arrefecido o debate em torno de sua natureza e do seu equilíbrio. Como observa R. J. Smith, é com a "constitutional dissention", que eclode no reino de Jaime I, que se despertou na Inglaterra o interesse pela história. ${ }^{6}$

Com efeito, em The ancient constitution and the feudal law, Pocock mostrara como nesse debate esteve em jogo interpretações concorrentes da história medieval inglesa - ou melhor, como uma certa interpretação da constituição enquanto "antiga constituição", defendida pelos common lawyers, em especial Edward Coke, se viu abalada pela descoberta da "lei feudal", isto é, de um conjunto de leis que regulavam

Nature, 9, 1990, pp.33-44.

2 Cf. BUCKLE, S. Natural Law and the Theory of Property. Grotius to Hume. Oxford: Clarendon Press, 1991.

3 Cf. HAAKONSSEN, K. The science of a legislator: the natural jurisprudence of David Hume and Adam Smith. Cambridge: Cambridge University Press, 1981.

4 Cf. MCARTHUR, N. David Hume's political theory, law, commerce, and the constitution of government. Toronto: University of Toronto Press, 2007.

5 Cf. BAIER, A. The cautious jealous virtue: Hume on justice. Cambridge/ London: Harvard University Press, 2010.

6 Cf. SMITH, R. J. The gothic bequest, medieval institutions in British thought, 1688-1863. Cambridge: Cambridge University Press, 1987, p.2. 
e acompanhavam a instituição social do feudo.

Segundo Pocock, a lei feudal já era conhecida na França pelos juristas do século XVI que se debruçaram sobre o Libri Feudorum, "a única sistematização escrita da lei feudal que se tornou parte da herança legal da Europa"7 e, em solo britânico, por Thomas Craig, um escocês formado na França que no início do século XVII sustentou a ideia de uma origem feudal e continental (ou seja, normanda) da lei escocesa, com base no seu conhecimento do Libri Feudorum, cujos traços se faziam notar nas práticas legais da Escócia. Mas a lei feudal era ignorada pelos juristas ingleses, acostumados a orientar suas práticas pelo conhecimento da common law, uma lei que se compreendia como especificamente inglesa e como imemorial. Sendo assim, de acordo com Pocock, os juristas ingleses não viam necessidade em inserir a common law num contexto europeu mais amplo e tinham forte resistência a lhe atribuir um caráter histórico.

A common law seria imemorial segundo os common lawyers por supostamente remontar a um tempo anterior à memória e aos registros históricos. Isso implica que ela não pode ser reconduzida a nenhum ato voluntário de fundação, sendo, antes, a sedimentação histórica de certos princípios fundamentais, cuja sabedoria e racionalidade se vêem confirmadas pelo costume, o uso ininterrupto e a atividade legislativa continuada, tendo por efeito o refinamento da lei. A teoria da common law é, assim, paradoxalmente, uma teoria segundo a qual a lei se funda no costume e em práticas continuadas - na história, portanto - e, por isso mesmo, é a-histórica, já que o costume não faz senão sedimentar certos princípios fundamentais que a lei reflete e que não são eles próprios alterados com a história, sendo, ao contrário, o que permanece imutável e contínuo através dos tempos ${ }^{8}$.

Eis a razão pela qual, à diferença da França, o feudalismo foi descoberto na Inglaterra não por juristas, mas por antiquarians, coletores de antiquities ou estudiosos de documentos históricos, movidos menos por questões de ordem jurídica e constitucional do que pela curiosidade e o desejo de erudição. Foi assim que Spelman, entre outros antiquarians da Society of Antiquaries, chamou atenção para as instituições feudais. Mas Spelman o fez, ainda segundo Pocock, de modo não sistemático e sem retirar da sua descoberta as consequências que levariam à necessária revisão da tese dos common lawyers acerca do caráter imemorial da lei. Se há algo como uma lei feudal, ligada ao feudo e às relações sociais de vassalagem instituições sociais que naquele momento já haviam entrado em declínio -, e se a lei feudal é parte da common law, então esta não é a sedimentação de princípios perenes e imemoriais, mas algo que se produziu na história e que com ela se transformou. Essas consequências só foram retiradas, porém, muito depois, após a restauração,

7 POCOCK. J. G. A. The ancient constitution and the feudal law. New York: Norton library, 1967, p.70. 8 Cf. Idem, pp.36-7. 
quando então o imemorialismo entrou em declínio, vitimado pelas novas e inegáveis evidências em favor da lei feudal.

Enquanto Pocock atribui a "common law mind" o atraso na assimilação da história feudal por parte dos juristas ingleses, Smith salienta que o que esteve por trás desse atraso, mas também o que fez avançar os estudos da história medieval, foi o debate em torno da natureza da constituição inglesa, que ele reconstrói nos momentos subsequentes à retomada das descobertas de Spelman por Brady (onde termina Pocock), após a restauração, quando então as evidências em favor do feudalismo passaram a ser mobilizadas em favor da causa do rei. As diversas partes envolvidas no debate se viram então obrigadas a desenvolver uma interpretação própria da história medieval, de modo que o debate constitucional se desenrolou como uma disputa em torno da interpretação da história inglesa.

Hume não foge à regra: trata-se também para ele de posicionar-se sobre a natureza e o balanço da constituição inglesa e de justificar sua posição a partir de uma certa interpretação da história da Inglaterra. 0 debate constitucional inglês perpassa, portanto, a sua História. Com relação a este debate é minha intenção mostrar que a contribuição de Hume consistiu em compreender a constituição e lei inglesas de uma maneira integralmente histórica, mostrando que não há nada nelas que escape à história - com o que Hume se opõe à ideia de uma suposta lei fundamental da Inglaterra, uma ideia recorrente, como mostrou e documentou Gough", ao longo do debate constitucional.

Ao reconstruir o sentido dessa expressão no interior do debate constitucional inglês, importa a Gough mostrar que o termo não tem o significado que adquiriu na constituição americana, a saber, a de princípios legais pétreos, que não podem ser modificados ou suprimidos pela legislação ordinária e a partir dos quais se pode operar algum tipo de controle de constitucionalidade. Essa ideia não encontra lugar na constituição atual da Inglaterra e não é de algo como um controle de constitucionalidade que se tratava, segundo Gough, quando nos séculos XVII e XVIII inglês se aludia à "lei fundamental”. Assim, ele mostra de maneira abundantemente documentada que os atos do parlamento e mesmo a Magna Carta (um documento assinado pelo Rei e os barões no século XIII, colocando limites às prerrogativas reais, extremamente aludido e enaltecido por Coke e os whigs) não eram tidos por "fundamentais". O que era tomado por fundamental era a lei natural e a razão que esses atos expressam e reafirmam, os princípios de justiça que a lei encarna.

Assim, por exemplo, segundo Gough, Coke

denomina lei fundamental, não o conjunto da common law, mas suas regras e "pontos fundamentais", ou, para empregar uma fraseologia mais moderna, os princípios

9 GOUGH, J. W. Fundamental Law in the English Constitutional History. Oxford: Oxford University Press, 1955. 
fundamentais da constituição. O Parlamento tinha o poder de fazê-los cair, se o decidisse; mas, se se podia sempre esperar que não o fizesse, não havia nenhuma lei superior que pudesse verdadeiramente impedi-lo. ${ }^{10}$

Noutros termos: não se pensava que a limitação da atividade legislativa do parlamento fosse de ordem legal, mas que consistisse nos direitos e deveres morais que supostamente suas leis encarnavam e reafirmavam. A lei fundamental é, portanto, a razão que se revela nas instituições históricas, nos costumes e nas leis estabelecidas, e o que permanece imutável ao longo da história.

Segundo Gough, a ideia de lei fundamental entra em declínio no final do século XVIII conforme entra em cena a ideia de soberania do legislativo, um movimento, consagrado segundo ele por Bentham, que porá fim ao império da lei fundamental. ${ }^{11}$ Embora Gough não o mencione, Hume é uma peça chave no declínio da ideia, ou pelo menos alguém que produziu um bom contraponto para ela em sua História da Inglaterra, como é bem reconhecido por diversos leitores da História, dentre os quais Pocock ${ }^{12}$. Minha intenção aqui é a de acompanhar de perto o modo como Hume desconstrói a ideia de lei fundamental no volume I da História da Inglaterra para ver emergir a partir desse pano de fundo a sua própria concepção da lei enquanto instituição social.

O volume I foi um dos últimos a serem escritos. Os primeiros volumes escritos e publicados (os V e VI da edição completa) são os últimos na ordem cronológica, dedicados ao período da monarquia Stuart, o período em que estourou a guerra civil inglesa, em que se deu a formação dos partidos e que conduziu à Revolução Gloriosa e à consolidação da constituição mista inglesa. Ou seja, o período da dissenção constitucional de onde Hume parte no seu interesse pela história da Inglaterra. Posteriormente, Hume escreveu os volumes dedicados às monarquias Tudor, e, depois, aqueles concernentes ao período "bárbaro", anterior a Henrique VII. A História da

10 Idem, p.50.

11 “É com o princípio de utilidade de Bentham (ainda que apenas um novo avatar da lei natural) e a introdução de reformas parlamentares, que a posição moderna [isto é, a ideia da soberania do Parlamento] começou verdadeiramente a emergir. Foi então que os vestígios da ideia de lei fundamental começaram a desaparecer" (GOUGH, J. W. Fundamental Law in the English Constitutional History, p.206). No entanto, a ideia de lei fundamental e de soberania parlamentar podem conviver perfeitamente; a primeira não precisa ceder lugar à segunda para que esta possa se afirmar. É o que mostra Waldron com relação a Locke (Cf. WALDRON, J. A Dignidade da Legislação. São Paulo: Martins Fontes, 2003, cap.3). Waldron mobiliza Locke contra Rawls, mostrando que a lei natural não era pensada por Locke como cláusulas invioláveis - como quer Rawls em relação aos princípios da justiça, pretendendo-se nisso um herdeiro de Locke - mas como um horizonte de deliberação, cabendo ao poder legislativo determinar o conteúdo da lei natural, segundo o seu critério e arbítrio, que se exerce presumivelmente em acordo com a razão e segundo a consciência, mas que não está submetido a nenhum tipo de controle legal. Esta é precisamente a ideia de lei fundamental, a que se referre Gough, frequentemente associada à ideia de lei natural no debate constitucional, a qual também adere Locke, e contra a qual Hume escreve.

12 Cf. POCOCK, J. G. A. Barbarism and Religion, II. Cambridge: Cambridge University Press, 1999, p.204. 
Inglaterra foi escrita de trás para frente.

Este primeiro período da história inglesa - o período bárbaro - contém alguns tópicos particularmente importantes em função do significado atribuído a eles na discussão constitucional, tais como a liberdade saxã, a conquista normanda e a Magna Carta. No volume I, Hume dá sua posição com relação a esses tópicos, fazendo culminar sua narrativa na celebração da Magna Carta. Esta, segundo ele, abre uma nova era na história inglesa - a história da sua constituição positiva, a ser narrada a partir do volume II. O que se tem, portanto, no volume I é a narrativa da pré-história da constituição. Nisso reside o seu interesse.

A compreensão que Hume tem desses eventos não é original, ele segue Brady e Spelman, os quais cita e aos quais se filia expressamente, valendo-se assim de uma historiografia a essa altura já consagrada e fundamentalmente tory, isto é, uma historiografia que dava sustentação aos argumentos daqueles que defendiam a causa do rei. Daí porque seja comum atribuir-se a Hume um progressivo conservadorismo e alinhamento com os tories..$^{13}$ Hume, por sua vez, pretende-se imparcial, nem Tory, nem Whig - e penso que ele não está muito distante disso, não havendo de todo modo uma guinada conservadora, mas o desenvolvimento dos elementos pró-tories ou nãowhigs presentes desde o princípio em sua filosofia da lei, já desde o Tratado.

0 que pretendo fazer aqui é deixar indicado, a partir da reconstrução da posição de Hume com relação a esses tópicos da história inglesa no volume I da História da Inglaterra, como ali se recusa a visão da lei enquanto lei fundamental em favor de uma visão integralmente histórica da lei enquanto instituição social.

\section{A liberdade saxã}

Hume começa o volume I da História da Inglaterra com as invasões germânicas - com a chegada dos saxões em solo britânico, o que culminou, 460 anos depois, no que ele reconhece como a primeira monarquia inglesa, a de Alfredo. É aqui precisamente que se inicia a sua história da lei inglesa - na história da lei saxã, que começa a ganhar forma então.

A valorização da herança saxã era um ponto central no modo whig de ler a história da Inglaterra no período posterior à restauração da monarquia. As teorias góticas, influenciadas pela descrição que Tácito e Cesar fizeram dos costumes e instituições dos povos germânicos, enfatizavam a liberdade de que supostamente

13 Ver, por exemplo, Giarrizzo, para quem Hume teria com o tempo se afastado dos whigs e se aproximado dos tories, na medida em que alargava o espaço da autoridade sobre a liberdade. Cf. GIARRIZZO, G. David Hume politico e storico. Torino: Einaudi, 1962. Embora não caiba desenvolver esse ponto aqui, penso, no entanto, que o lugar da autoridade está assinalado com bastante precisão no sistema jurídico de Hume desde o Tratado. O que Hume fez foi desenvolver, posteriormente, nos Ensaios e na História da Inglaterra, os contornos da teoria da autoridade necessária para completar o seu pensamento jurídico. Cf. GIARRIZZO, G. David Hume politico e storico. Torino: Einaudi, 1962. 
gozavam os saxões entre o fim da ocupação romana e a conquista normanda. A exaltação da liberdade gótica desempenhou no argumento whig do período posterior à restauração o mesmo papel desempenhado pelo recurso, comum no período anterior à guerra civil, ao caráter imemorial da common law ${ }^{14}$. 0 que se trata de defender num e noutro caso é o caráter fundamental da lei.

O maior advogado da common law e de seu caráter imemorial foi Coke, a cuja obra se recorria ao longo do debate constitucional como a uma espécie de "oráculo do direito"15. Coke foi amplamente usado e citado pelos whigs a favor da sua causa, de modo que se pode dizer que foi um whig por "afiliação póstuma". ${ }^{16}$

A tese fundamental de Coke e que reflete a percepção que os common lawyers tinham da lei inglesa é a de que esta se deriva de costumes imemoriais e que é em função do uso continuado desde os tempos imemoriais que a lei e as práticas jurídicas das quais se tem registro adquiriram força de lei. A lei é, assim, a prescrição de costumes imemoriais. Daí porque, quando se trata de legitimar um determinado princípio, seja o caso de encontrar o maior número possível de práticas e registros que confirmem seu caráter antigo. Tais registros não valem por si mesmos, de acordo com a common law mind (segundo a expressão de Pocock), enquanto fonte de autoridade da lei, mas na medida em que deles se pode depreender costumes ainda mais antigos e, no limite, imemoriais, dos quais eles seriam supostamente derivados e de que seriam a confirmação.

O raciocínio funda-se sobre a tese de que o uso continuado de um princípio, a sua permanência no tempo, é a prova de que ele é bom e benéfico, funcionando como uma espécie de atestado de perfeição da lei. A lei proveniente do costume, a customary law é a mais perfeita e excelente porque é a sedimentação da sabedoria de muitas gerações. Coke enfatiza ainda a atividade constante dos juízes no aprimoramento e refinamento da lei como um elemento que dá à common law a sua autoridade. 0 uso costumeiro atesta ainda que a lei provém de um consentimento tácito entre os ingleses, que a lei da Inglaterra não é, portanto, estrangeira ou imposta, mas a lei dos ingleses, contraparte inseparável da sua liberdade.

Essa teoria da lei enquanto prescrição do costume esteve fortemente atrelada ao que Pocock denomina o mito da antiga constituição, uma constituição que teria sido a dos saxões e que - este é um ponto de honra para Coke e os common lawyers não se viu alterada pela invasão normanda, tendo sido, ao contrário, reafirmada pelos normandos, de modo a ter se transmitido por repetidos atos de confirmação desde os

14 Cf. SMITH, R. J. The gothic bequest, medieval institutions in British thought, 1688-1863, pp.11-3 15 WESTON, C. C. “L'Anglaterre: l'ancienne constitution et le droit commun”. In: Burns, J. H. (org.) Histoire de la pensée politique moderne, 1450-1700. Paris : PUF, 1997, p.341.

16 SMITH, R. J. The gothic bequest, medieval institutions in British thought, 1688-1863, p.2. Sobre a influência póstuma de Coke, ver ainda POCOCK. J. G. A. The ancient constitution and the feudal law, pp.45-6. 
tempos imemoriais até o presente. Tratou-se na verdade de projetar a constituição inglesa do século XVII no passado, sendo um ponto fundamental ao imemorialismo a defesa do caráter imemorial do próprio parlamento e da casa dos comuns. Daí porque os whigs tenham encontrado no imemorialismo argumentos preciosos para a sua causa a favor das limitações das prerrogativas reais: uma constituição imemorial é uma constituição independente do rei e de seu poder, operando como um fator limitador desse poder.

A teoria gótica foi, a princípio, segundo Smith, uma teoria rival ao imemorialismo, já que o interesse pelos costumes e leis saxãs e a coleta dos registros históricos do período respondem a uma curiosidade de ordem histórica, favorecendo a visão de uma origem temporal e não imemorial da lei. Além disso, a valorização da liberdade saxã convivia bem com a ideia, também em circulação no período, por exemplo entre os levellers, mas negada pelos imemorialistas, de que a invasão normanda foi um ato de conquista pela violência, consistindo na submissão pela força dos saxões por parte dos normandos e na imposição de um jugo a ser afastado. A conquista normanda era negada pelos common lawyers, que não falavam em conquista, mas de um acordo entre saxões e normandos em torno da lei fundamental. ${ }^{17}$

Mas, quando o imemorialismo se viu definitivamente vitimado pela descoberta do feudalismo, após a restauração, a teoria gótica ganhou força entre os whigs, por ser menos atingida que o imemorialismo pelos estudos históricos. Ela oferecia aos whigs um novo modo de pensar a lei fundamental, agora entendida como saxã. Smith mostra como na ideologia whig pós-restauração, a teoria gótica aliou-se ao maquiavelismo e ao harringtonismo - isto é, à ideia de que é preciso retornar ao espírito original da constituição, renovar seus compromissos e salvá-la da corrupção histórica - ganhando força sobre o imemorialismo na sustentação da ideia de que existe algo como uma Lei inglesa fundamental, servindo como um elemento de limitação da autoridade real. Quer fosse imemorial, quer fosse uma herança do período gótico, em ambos os casos importava apontar para a existência de uma lei fundamental ou de uma antiga constituição inglesa, a ser preservada ou reestabelecida. A exaltação da liberdade gótica era uma forma de mostrar a sua existência na história, fazendo-a remontar ao período de fundação do corpo político inglês.

Hume introduz os saxões em sua narrativa histórica exaltando, ele também, a liberdade germânica:

De todas as nações bárbaras, conhecidas nos tempos antigos ou modernos, os germanos são os que mais se distinguem, tanto por suas maneiras quanto por suas instituições políticas, e os que elevaram ao mais alto grau as virtudes do valor e do amor à liberdade [liberty], as únicas virtudes que podem encontrar lugar entre povos não civilizados,

17 Cf. SMITH, R. J. The gothic bequest, medieval institutions in British thought, 1688-1863, p.5; WESTON, C. C. "L'Anglaterre: l'ancienne constitution et le droit commun", In: Burns, J. H. (org.) Histoire de la pensée politique moderne, 1450-1700, p.346 ; POCOCK, cap. 2, II. 
onde a justiça e a humanidade são normalmente negligenciadas. 0 governo do rei, mesmo quando estabelecido entre os germanos (pois não o era universalmente), possuía uma autoridade bastante limitada; e embora o soberano fosse usualmente escolhido entre os da família real, ele era conduzido em todas as decisões [in everymeasure] pelo consentimento comum da nação a que presidia ${ }^{18}$.

Também no apêndice com o qual se fecha a narrativa do período, a apresentação do governo e das maneiras anglo-saxãs se introduz pelo topos da liberdade germânica:

0 governo dos germanos e de todas as nações nórdicas que se estabeleceram nas ruínas de Roma eram sempre extremamente livres [free]; e esse povo feroz [fierce], acostumado à independência e habituado às armas, era guiado mais pela persuasão do que pela autoridade, na submissão que prestava a seus príncipes (...). As constituições livres então estabelecidas, ainda que prejudicadas pela usurpação [encroachments] de sucessivos príncipes, ainda preservam o ar da independência e da administração legal que distingue as nações europeias; e se essa parte do globo mantém os sentimentos de liberdade, honra, equidade e valor em grau superior ao resto da humanidade, deve tais vantagens principalmente às sementes plantadas por esses generosos bárbaros ${ }^{19}$.

A referência é Tácito: "o mesmo retrato [picture] de uma feroz [fierce] e impudente [bold] liberdade, desenhado pelo pincel magistral de Tácito, caberá aos fundadores do governo inglês. ${ }^{20}$ Hume incorpora no seu retrato dos saxões o traço, bem definido no retrato que Tácito fizera dos povos germânicos, segundo o qual os príncipes germânicos governavam com a ajuda de um conselho nacional ou uma assembleia de sábios, sendo antes um príncipe - o “primeiro entre os cidadãos” - do que um rei.

Há, deste modo, “ecos de goticismo" em Hume ${ }^{21}$. Mas o topos da liberdade germânica é para Hume apenas um ponto de partida, que dele se apropria para alterar profundamente o seu significado corrente no interior do debate constitucional. Não apenas ele evita fazer deste quadro da liberdade a prova de que a estrutura presente do parlamento já estivesse bem estabelecida entre os saxões ${ }^{22}$, como o associa antes à carência de governo e à ausência da lei do que à expressão de um equilíbrio constitucional fundamental.

Se a autoridade real era limitada entre os saxões, não é porque o governo fosse bem equilibrado, mas porque era incipiente - um governo que mal começara a se estabelecer em torno de sua capacidade ainda muito restrita de conter a violência

18 HUME, D. The History of England, 6 vols. Indianapolis: Liberty Fund, 1983, p.15 - doravante H, I. 19 Idem, p.160.

20 Idem, p.161. Sobre a importância de Tácito - em especial, sobre o caráter exemplar dos seus retratos históricos para Hume e seus contemporâneos, ver o ensaio de Pedro Pimenta "A arte do retrato histórico" (PIMENTA, P.P. A imaginação crítica, Hume no século das Luzes. Rio de Janeiro: Azougue, 2013).

$21 \mathrm{SMITH}, \mathrm{R}$. J. The gothic bequest, medieval institutions in British thought, 1688-1863, p.79.

22 “Nosso conhecimento das 'antiquities' e da história anglo-saxã é por demais imperfeito para nos dar os meios de determinar com certeza todas as prerrogativas da coroa e os privilégios do povo, ou para dar o contorno [delineation] exato de um tal governo", pondera (H, I, p.162). 
generalizada, a pilhagem corrente e as sucessivas invasões estrangeiras. Se os governos saxões lançaram as sementes de uma "monarquia civilizada, dotada de tranquilidade interna e segura contra as invasões externas" ${ }^{23}$, estavam muito distantes de ser uma. Uma monarquia civilizada é para Hume um governo regulado pela lei, opondo-se nisso às monarquias bárbaras. Estas são arbitrárias - entenda-se: sem lei, ou melhor, com uma lei apenas incipiente. Pode-se ler a História da Inglaterra como a história da passagem da monarquia bárbara à civilizada, o que passa pela constituição de um sistema legal ${ }^{24}$.

Assim, as sementes da monarquia civilizada semeadas pelos bárbaros saxões foram as sementes da lei. Trata-se de uma certa capacidade de executar e administrar a justiça que o governo saxão adquiriu sobretudo a partir de Alfredo ${ }^{25}$, sendo a administração da justiça a função principal do governo e aquilo que explica a sua existência, conforme a teoria do governo presente no Tratado e nos Ensaios. ${ }^{26} \mathrm{E}$ é em torno desta administração que o primeiro governo inglês - o saxão - se organiza, sendo assim o princípio (no sentido do começo) de uma monarquia civilizada.

0 mérito de Alfredo está em ter organizado uma milícia regular que garantiu a defesa da Inglaterra frente aos ataques estrangeiros ${ }^{27}$ e, paralelamente a isso, em ter garantido alguma paz interna pela elaboração de um "plano para a administração da justiça"28. Este plano consistiu basicamente em dividir a Inglaterra em condados, subdividi-los em centos e décimos e responsabilizar cada unidade pelas ofensas cometidas pelos seus, fazendo com que os membros das comunidades arbitrassem em conjunto as diferenças entre eles e que as comunidades maiores arbitrassem as diferenças entre as menores. Quanto a esse "método de decisão", Hume observa que é "a origem dos juris; uma instituição admirável em si mesma e a melhor calculada para a preservação da liberdade e a administração da justiça jamais divisada pelo engenho humano"29.

Há nessas observações novos "ecos de goticismo", temperados com uma boa

23 Idem, p.50.

24 Cf. MCARTHUR, N. David Hume's political theory, law, commerce, and the constitution of government.

25 Cf. H, I, p.75.

26 Ver por exemplo o ensaio Da origem do governo: “o homem (...) é levado a estabelecer a sociedade política a fim de administrar a justiça, sem a qual não pode haver paz, segurança ou intercâmbio entre os homens" (HUME, D. Essays Moral, Political and Literary. Miller, E. (ed.). Indianapolis: Liberty Fund, 1985, p.37).

27 "Ele ordenou que toda a população fosse armada e registrada; atribui-lhe uma rotação regular de deveres; distribuiu uma parte em castelos e fortalezas, construídos em lugares apropriados; determinou que outra parte ganhasse o campo ao primeiro alarme e se reunisse em lugares estabelecidos de encontro; e deixou um número suficiente em casa, empregados no cultivo da terra, e que depois tomavam seus lugares no serviço militar" (H, I, p.70).

28 Idem, p.77.

29 Idem, ibidem. 
dose de imemorialismo, uma vez que Hume observa ainda que Alfredo não foi "o único autor desse plano de governo"; antes, "como um homem sábio, ele se contentou com reformar, estender e executar as instituições que ele encontrou

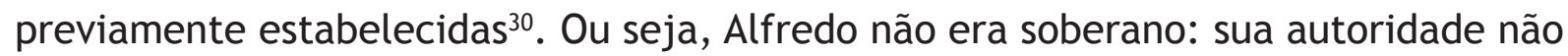
era a fonte, ou ao menos não a única fonte - com o que Hume aceita um ponto central da historiografia whig. Sua concessão é coerente com a teoria da lei natural do Tratado, segundo a qual a lei encontra o seu princípio (no sentido do começo) nos acordos recíprocos e nas práticas comuns que se estabelecem antes mesmo de haver governo. Há lei natural antes do governo e esta constitui-se em práticas acordadas estabilizadoras da posse. Assim, o governo surge para administrar uma lei préexistente nos princípios acordados que regulam as práticas sociais e que dão certa estabilidade, ainda que muito precária, à propriedade. Tais práticas necessitam, porém, da administração de um governo para que se tornem elas próprias regulares, para que se tornem um sistema de regras, no que consiste para Hume a justiça.

Mas um tal sistema de regras é justamente o que falta à sociedade saxã:

Entre um povo que vive de maneira tão simples quanto os saxões o poder judicial é sempre de maior importância que o legislativo. Havia poucas ou nenhuma taxa imposta pelos estados, poucos estatutos decretados; e a nação era menos governada pelas leis do que pelos costumes [customs], que admitem uma grande latitude de interpretação. ${ }^{31}$

Assim, não havia propriamente leis entre os saxões. O que se tinha era a lei natural: "devemos conceber que os antigos germanos pouco tinham se afastado do estado de natureza original" 32 . Da lei civil havia apenas rudimentos, que culminaram nas leis coletadas por Eduardo, o Confessor, o último da linhagem saxã, acerca das quais Hume observa que, embora estivessem "hoje perdida[s] (pois as leis que se passam em nome de Eduardo foram compostas depois), [foram] por muito tempo objeto de afeição da nação inglesa" 33 . Com efeito, as supostas leis de Eduardo eram tidas como um dos primeiros atos de prescrição da common law, um atestado de sua imemorialiadade. Mas Hume se refere a esse suposto corpo de leis como o rudimento de um código civil e de uma lei escrita da qual não restou nenhum registro e que não chegou a marcar a presença reguladora da lei civil na sociedade saxã.

Tal sociedade carecia de leis porque a ela faltava um poder legislativo. As cortes saxãs, cujo caráter deliberativo tanto se exaltara no debate constitucional, não eram cortes legislativas, mas judiciárias, que arbitravam as diferenças de modo bastante irregular, segundo a discrição dos magistrados, de acordo com "a grande latitude de interpretação" admitida pelos costumes de que se serviam como regra

30 Idem, p.79.

31 Idem, p.173

32 Idem, p. 174.

33 Idem, p.146. 
em sua atividade judiciária.

Penso que Hume entende por costume nessa passagem o mesmo que lei natural, ou seja, um conjunto de práticas mais ou menos acordadas, mais ou menos sedimentadas e ainda não sistematizadas que traziam alguma estabilidade à propriedade. Se é assim, vale lembrar que no Tratado Hume salienta que, nas deliberações jurídicas que se fazem com base apenas na lei natural (isto é, sem o apoio de uma lei civil), em boa parte dos casos, não há um critério [standard] dado pelo qual se possa orientar ou regular a decisão. ${ }^{34}$ Esta será, portanto, arbitrária; criar tais critérios é um papel decisivo da lei civil e do poder legislativo, cuja presença é um fator de limitação do poder discricionário dos magistrados.

Mas, justamente, não havia - ou quase não havia - tal poder legislativo entre os saxões. O que se tinha era um certo método de decisão judicial a partir da lei natural, pelo qual a justiça era administrada de maneira irregular e discricionária ou arbitrária. E nisso consistia, segundo Hume, o caráter consentido da lei saxã: nos costumes e práticas legais, cuja latitude deixava aos magistrados das cortes de justiça um amplo poder discricionário, em face da ausência de um poder legislativo e de uma lei escrita que viesse a fixar um padrão de decisão para as disputas judiciais. Estamos bem distantes do topos da liberdade germânica, como o elemento de um equilíbrio constitucional antigo ou imemorial a ser preservado no presente.

Além disso, no que tange ao poder legislativo, ainda mais precário entre os saxões do que o judiciário, Hume o vincula à autoridade igualmente precária dos reis - com o que se afasta ainda mais da historiografia whig, fazendo eco às teorias da soberania que, de Bodin a Filmer, municiaram os tories no debate constitucional. Como vimos, Hume entende que os reis saxões não eram soberanos, que a lei saxã estava longe de ser um produto de suas vontades, já que provinha dos costumes e consistia em última instância na lei natural. Ainda assim, ele entendia que a autoridade dos príncipes era uma circunstância indispensável para a consolidação da

34 Hume observa, na contramão da tradição da lei natural, que "é fácil ver quão complicadas podem se tornar as diversas questões concernentes à aquisição da propriedade por ocupação e o menor esforço de pensamento pode nos apresentar exemplos que não admitem nenhuma decisão razoável [reasonable]. Se preferimos exemplos reais aos imaginados [feign't], podemos considerar o seguinte, que se encontra em quase todos os autores que trataram da lei natural. Duas colônias gregas, tendo deixado seu país natal em busca de novos assentamentos, foram informadas de que uma cidade próxima havia sido abandonada por seus habitantes. Para confirmar a veracidade do relato, elas de pronto enviaram dois mensageiros, um de cada colônia, os quais, ao se aproximarem, tendo descoberto que a informação era verdadeira, começaram uma corrida com a intenção de tomar posse da cidade, cada qual em nome dos seus conterrâneos. Um dos mensageiros, vendo que não era tão veloz quanto o outro, atirou sua lança nos portões da cidade e teve a sorte de fixá-lo ali antes da chegada do seu companheiro. Isso produziu uma disputa entre as duas colônias sobre qual delas era a proprietária da cidade abandonada; e esta disputa ainda subsiste entre os filósofos. De minha parte penso que a disputa é impossível de ser decidida, e isso porque toda a questão depende da fantasia [fancy], que nesse caso não possui nenhum padrão [standard] preciso e determinado a partir do qual possa dar a sua sentença (HUME,D. A Treatise on Human Nature. Selby-Bigge/ Nidditch (eds). Oxford: Clarendon Press, 1989, pp.507-8, nota, grifos meus). 
lei enquanto elemento de regulação social. Eis porque ele não economiza elogios a Alfredo, exaltando as virtudes que sustentavam sua autoridade legislativa:

0 mérito deste príncipe, tanto na vida privada quanto pública, pode se contrapor com vantagem ao de qualquer monarca ou cidadão apresentado nos anais de qualquer época ou nação. Com efeito, ele parece ser o modelo daquele caráter perfeito, que, sob a denominação de um sábio ou de homem sábio, os filósofos quiseram delinear, mais como uma ficção de sua imaginação do que na esperança de vê-lo alguma vez existindo realmente ${ }^{35}$.

Tais méritos permitiram que Alfredo garantisse com seu governo alguma tranquilidade social - bons efeitos da administração da justiça - que, por sua vez, deram a ele uma certa autoridade, com a qual pode então governar ou administrar a justiça, num círculo virtuoso que favoreceu a implantação da lei. O importante a assinalar é que sem a autoridade de Alfredo o pouco de lei que houve entre os saxões sequer teria existido. Sem a "vigilância e a atividade de Alfredo" 36 - escreve Hume - sua precária administração da justiça teria sucumbido ao barbarismo, ao regime de violência e ausência de regulação legal ainda imperante. Ou seja, a lei está na dependência de uma instância de governo ativa - uma autoridade. No caso de Alfredo, sua autoridade esteve fundada sobre o seu bom governo, embora se explique ainda por outras circunstâncias, mais particulares e menos dependentes do seu valor: além das urgências do tempo e da aprovação da nação, Alfredo foi chamado ao trono - observa Hume - pela vontade de seu pai, "uma circunstância que tinha grande autoridade entre os anglo-saxões" ${ }^{37}$. Seja lá como for constituída a autoridade do rei (este é um ponto interessante, mas que não cabe ser desenvolvido aqui), importa observar que ela não equivale, mas excede e engloba a autoridade da lei, sendo o que permite que a lei venha a ter sua autoridade própria, na medida em que se consolida em torno da autoridade real.

Outras circunstâncias relacionadas à autoridade dos príncipes saxões são assinaladas por Hume com relação a Eduardo, O Confessor - príncipe cujo governo cumpriu também um papel decisivo no desenvolvimento da lei saxã. Hume faz ver que a autoridade deste príncipe, tido por santo, esteve fundada em boa medida sobre sua religiosidade, uma qualidade valorizada em tempos de superstição, e sua submissão a Igreja, instituição que gozava então de autoridade própria, da qual dependia em boa parte a autoridade dos príncipes. Hume quer mostrar com isso, e com os relatos das disputas de poder frequentes entre cléricos e os príncipes saxões, a precariedade da autoridade destes últimos, ao mesmo tempo em que aponta para as circunstâncias sociais particulares em que esta autoridade se funda, assim como

$35 \mathrm{H}, \mathrm{I}, \mathrm{p} .74$.

36 Idem, p.76.

37 Idem, p.64. 
assinala seu caráter indispensável à administração da justiça.

Na narrativa de Hume, a autoridade nascente do governo saxão esteve ameaçada não apenas pela autoridade nem sempre convergente dos clérigos, como também e de forma decisiva, pelas querelas de sucessão e pelo poder de uma nobreza cada vez mais empoderada. Assim, Hume narra como um certo conde Godwin, cuja família tinha grande autoridade "sustentada por posses imensas e alianças poderosas" 38 , se opôs a Eduardo. Se Eduardo gozava da afeição dos ingleses - logo, de autoridade - Godwin, por outro lado, "fixou sua autoridade em bases firmes", de modo que a de Eduardo restou bastante diminuída diante de sua oposição. 0 rei não deixou de defenderse, procurando, por exemplo, fortalecer uma família rival, adotando a "a política [policy] de balançar os partidos opostos" a fim de estabelecer uma balança entre "as famílias potentes". Mas sua política não surtiu o efeito desejado ${ }^{39} \mathrm{e}$ as turbulências e intrigas entre as famílias nobres se prolongaram no governo de Haroldo, precipitando a invasão normanda e prolongando-se por todo o período bárbaro, até o governo de Henrique VII, quando então a monarquia se consolida como uma autoridade capaz de fazer frente ao poder dos barões.

O que se vê nessas passagens na História da Inglaterra é uma certa visão maquiaveliana da sociedade como um campo de forças que Hume herdará de Harrington, mas sendo ainda mais maquiaveliano do que este, no papel que atribui à autoridade do príncipe para a estabilização desse campo. Vem de Maquiavel o conselho de que o príncipe deve balançar os partidos opostos - o famoso "dividir para governar" a que Kant alude no apêndice a Paz Perpétua, como o preceito de uma política que se pensa como independente da moral, e que Hume diz ter sido posto em prática, ainda que sem sucesso, por Eduardo, o Confessor. Mais sucesso teria a boa administração da justiça na consolidação da sua precária autoridade. Seja como for, a alusão ao preceito maquiaveliano de prudência política nesse contexto é uma forma de corroborar a sua visão de que é preciso de algum modo estabilizar o campo das forças sociais para que a lei possa se impor - e que isso só pode ser feito - nesse começo pelo menos, em que a lei tem que se impor sobre a ausência da lei - pela consolidação da autoridade do príncipe.

Este não era o caso, porém, do governo de Eduardo. Se Eduardo procurou administrar com rigor a justiça, ele ainda assim não dispunha da autoridade necessária para conter a violência dos mais potentes. Daí a precariedade da lei durante o seu governo, assim como no período saxão como um todo.

A partir desse ponto Hume pode retomar em novos termos a questão da formação dos conselhos legislativos que teriam existido entre os povos germânicos, com os quais os reis teriam supostamente partilhado sua autoridade legislativa. Hume

38 Idem, p.133.

39 Idem, p.137. 
aceita, com bastante reserva, que um tal conselho tenha de fato existido entre os saxões. Há poucas evidências, mas parece [“it appears”] - diz ele - que algo assim tenha existido e o que rei governasse, portanto, com a ajuda de um conselho ${ }^{40}$.

Mas, se existiu, tal conselho de modo algum prefigurou o parlamento dos séculos XVII e XVIII, com sua casa dos comuns. Eram conselhos aristocráticos, afirma Hume, apoiando-se nos estudos de Brady, sem contudo abandonar a autoridade de Tácito, que procura conciliar com Brady. Tácito não dizia, observa Hume, que os conselhos germânicos eram representativos, mas que o consentimento de toda a comunidade era requerido nas deliberações. São coisas bem distintas. Do elemento supostamente consentido da lei saxã Hume dera conta ao se referir aos costumes e práticas consentidas (lei natural), que regulavam as decisões dos magistrados nas cortes judiciárias. Um conselho legislativo - fazedor da lei - é outra coisa. Não era isto a que Tácito se referia, podendo-se ficar com Brady sem desautorizá-lo: se, além das cortes judiciárias, um tal conselho legislativo existiu entre os saxões, ele era um conselho aristocrático, composto pelos grandes proprietários de terra, e não um conselho representativo dos comuns. A esta visão bradyana da composição dos conselhos legislativos Hume acrescenta a visão harringtoniana segundo a qual o que estava em jogo então era a disputa de poder entre o rei e os nobres, que mais enfraquecia do que compunha a autoridade legislativa.

Assim, é verdade que o poder dos reis saxões não era um poder absoluto. Além de aplicar a lei natural com a ajuda de magistrados dotados de amplos poderes discricionários, os reis saxões não decidiam a composição dos conselhos legislativos que teriam existido no período. Hume recusa a ideia, que era a de Brady e a dos tories, de que os participantes dos conselhos legislativos saxões eram designados pelo rei $^{41}$. Mas, se o faz, não é para se aproximar da visão whig de que a Inglaterra já seria então dotada de uma constituição equilibrada e de um governo representativo, mas sim para reiterar a sua própria visão do período saxão, segundo a qual a autoridade legislativa era então precária, a lei incipiente e os interesses da nobreza prevalecentes.

Os nobres - os grandes proprietários e senhores de escravos - tinham força para pôr em cheque a precária autoridade legislativa do rei, com o que se fortaleciam ainda mais contra ela.

Grande propriedade dos nobres, especialmente quando aliada a uma administração irregular da justiça, naturalmente favorece o poder [power] da aristocracia; mas ainda mais se a prática da escravidão for admitida e tiver se tornado bastante comum. A nobreza não apenas possui a influência que atende aos ricos, mas também o poder que a lei the dá sobre escravos e vassalos. ${ }^{42}$

40 Idem, p.163.

41 Cf. Idem, p.165.

42 Idem, p. 171. 
É ainda sobre Brady que Hume se apóia para afirmar a forte presença da escravidão entre os saxões. 0 que ele quer retirar daí é uma explicação, que ele acrescenta à explicação harringtoniana de que o poder está fundado na propriedade, para o poder da nobreza. Não é apenas que um certo tipo de lei favorece a nobreza, mas a insipiência da lei a favorece, já que, nesse caso, subjugar-se aos grandes proprietários, como vassalo ou escravo, é a única saída, a título de proteção.

A suposta liberdade saxã não estava, portanto, na presença desses conselhos legislativos, em que tinham assento os grandes proprietários de terra e os senhores de escravo, e que apontavam antes para a precariedade da autoridade legislativa do que para um justo balanço constitucional. Nesse primeiro capítulo da história da lei, a autoridade legislativa está com o rei. E sendo ela precária diante do poder dos nobres, não podia haver entre os saxões "verdadeira liberdade" ${ }^{43}$, o que Hume entende, em termos republicanos, como proteção da violência dos poderosos pela lei. 0 que havia de liberdade entre os saxões não estava nos conselhos legislativos, mas na administração da justiça que começava a se organizar nas cortes judiciárias e que, segundo Hume, "era calculada para defender a liberdade geral e restringir o poder dos nobres" 4 .

Contudo, o poder de injuriar e decidir pela violência era muito maior que o judicial e o legislativo, e recaia sobre a nobreza, os proprietários de terra e de escravos. Eis porque, ao fim da sua narrativa sobre o período saxão, Hume prefere denominar a tão exaltada liberdade saxã de "licenciosidade". Na falta da lei, a violência, os roubos, os crimes e a necessidade de buscar proteção entre os mais fortes, que se viam ainda mais fortalecidos por essa dinâmica, eram a regra. A razão disso está na ausência da lei e na insegurança que isso gera - lição que Hume guarda de Hobbes e Selden. O que se tinha então, em sua leitura do período, era uma aristocracia com grande poder [power] de causar injúria e decidir as questões pela violência, o qual era maior que a autoridade legal, que, embora existisse, se exercia antes enquanto autoridade judicial do que legislativa, e de maneira bastante rudimentar e irregular, de modo a não ser capaz de se impor diante do poder dos nobres.

\section{A conquista normanda e a lei feudal}

Assim como o estudo histórico das instituições sociais saxãs mostra que a violência se sobrepunha à capacidade da lei de regular as relações sociais, a história também revela o caráter violento da conquista normanda. Tratou-se em última instância de uma dominação dos ingleses pelas armas por parte dos normandos e de

43 "Ao fim e ao cabo, não obstante a aparente liberdade, ou antes, licenciosidade dos anglo-saxões, a maioria dos cidadãos gozava de menos verdadeira liberdade do que pela execução mais severa da lei por parte de um magistrado civil" (Idem, p.168).

44 Idem, p.172. 
uma conquista que, pela força, alterou profundamente as relações de poder e de propriedade na Inglaterra (diferentemente da dominação romana, que as preservou). O caráter de conquista pela força da invasão normanda é um fato que, de acordo com Hume, só negam aqueles que foram "tomados pelas controvérsias de facção". Os historiadores mais próximos do evento falam inequivocamente "do domínio normando como uma conquista pela guerra e pelas armas"45.

Com efeito, embora admitida nos tempos da guerra civil por radicais como os levellers, que entendiam a conquista normanda como um jugo a ser suspendido, e por um autor pouco popular como Hobbes, cuja teoria política permitia pensar a conquista como o anteato da instituição da soberania por meio do contrato (o que Hobbes entende ser a soberania por aquisição), o caráter de conquista da invasão normanda era em geral negado tanto pelos defensores da causa do parlamento quanto pelos realistas ${ }^{46}$. Ambos os partidos recorriam ao mito da antiga constituição para afirmar as prerrogativas seja do parlamento, seja do rei ${ }^{47}$. Desse ponto de vista, entendiam a invasão normanda não como uma conquista, mas como um acordo entre saxões e normandos preservando as leis saxãs. Entender a invasão normanda como uma conquista pela força seria introduzir uma ruptura na história que poria a perder a continuidade e perenidade de uma suposta lei fundamental, cuja natureza estava no centro das discussões constitucionais.

É com Brady, após a restauração, na década de 80 do século XVII, que o tema da conquista ganhou importância no debate constitucional. Brady afirma o caráter de conquista da invasão como um argumento a favor da causa do rei, chamando atenção para a transformação social que a conquista acarretou, com a introdução da lei feudal ou do sistema de posse da terra que os normandos importaram do continente para a Inglaterra. Fundamentalmente, Brady quer retirar daí o argumento segundo o qual os senhores feudais e seus vassalos tinham seus direitos de assento e de representação no parlamento diretamente derivados do seu direito à propriedade da terra, que era uma concessão do rei, remontando a este, portanto, o fundamento da lei e da ordem constitucional.

Segundo Smith, a Revolução Gloriosa, em 1688, ao promover e admitir a quebra da linha sucessória, alterou o valor da conquista na polêmica, que passou

$\overline{45 \text { Idem, p.227. }}$

46 POCOCK. J. G. A. The ancient constitution and the feudal law, cap.7.

47 Sobre isso, escreve Smith: "Na série de crises que marcaram a evolução de nossa Constituição, o conflito sempre foi não entre a Constituição e sua negação ou sua ausência, mas entre as interpretações divergentes de uma Constituição da qual não se negava a existência. Tal era a situação no começo do século XVII (...). Os dois lados acreditavam na realidade de uma Constituição, e porque história e prescrição jogavam nisso um papel crucial, os dois lados foram forçados a olhar para trás e invocar o passado, e a aparecer como os defensores daquilo que era histórico, não mudado e - conforme sustentavam - imutável - em uma palavra, fundamental - contra as inovações e abusos ilegais" (SMITH, R. J. The gothic bequest, medieval institutions in British thought, 16881863, p.76). 
então a ser aceita pelos whigs (ainda que muitos ainda a negassem) como um evento que maculou a liberdade inglesa, de origem saxã.

Um século depois, Hume adere à tese já então bem estabelecida de uma diferença radical entre o feudalismo normando e o saxão, bem como a tese, um pouco mais polêmica, do caráter violento da conquista, como sendo aquilo que sustentou e permitiu a instauração do sistema de propriedade e da balança de poder normanda e, a partir daí, um tipo de lei e de constituição bastante diferente da saxã.

Segundo Hume, Guilherme, o Conquistador, a fim de conciliar o espírito dos ingleses com sua autoridade deu à conquista uma aparência de justiça ${ }^{48}$. Tudo se passou como se os ingleses tivessem consentido com a sua autoridade (esta é, como vimos, a visão por muito tempo dominante da conquista), mas na verdade esse consentimento lhes foi extorquido pela força das armas ${ }^{49}$. Que se tratasse de uma mera aparência de justiça é o que fica claro quando se vê que, logo após ter-se firmado na ilha, Guilherme retornou a Normandia, deixando os ingleses a mercê na rapacidade dos seus generais. Isso provocou uma mudança de sentimento nos primeiros, que passaram a se rebelar e a tramar contra os normandos, o que deu a ocasião para que fossem violentamente punidos, confiscados e excluídos dos cargos administrativos e eclesiásticos. A conquista mostrou assim a sua cara: tratou-se inegavelmente de submeter os ingleses pela força. Tratou-se de um jugo [yoke] normando ${ }^{50}$.

Quanto a tese de que o Conquistador teria respeitado e preservado as leis saxãs, Hume não hesita em dizer que se tratou de uma farsa:

No empenho de depreciar a nação inglesa, o rei, movido pelos protestos de alguns de seus prelados, e pelos mais veementes desejos do povo, restaurou algumas das leis do rei Eduardo, as quais, embora aparentemente sem importância para a proteção da liberdade geral, deu-lhes extrema satisfação, como o memorial de seu antigo governo, e uma marca não usual de complacência em seus imperiosos conquistadores. ${ }^{51}$

A passagem é interessante por jogar uma pá de cal em qualquer tentativa de ligar a liberdade saxã à lei saxã: esta lei não era capaz de proteger a "liberdade geral"! Por isso mesmo o Conquistador pode acatá-las, contentando os ingleses, mas não, como pensaram, como uma forma de atenuar e sim de aprofundar sua autoridade sobre eles. Guilherme conseguiu estabelecer sua "autoridade”, segundo Hume, "em parte em função de seu caráter veemente, em parte através de arte e dissimulação" 52 . Além da força, a autoridade do Conquistador fundava-se na aparência de justiça com que soube revestir o seu governo (este é, como se sabe, um

48 Cf. H, I, pp.188;189;192.

49 Cf. Idem, p.189.

50 Idem, p.195.

51 Idem, p.209.

52 Idem, p.225. 
tema maquiavelino por excelência!). A aceitação das leis de Eduardo por parte do Conquistador (um dos mitos da historiografia inglesa) é assim vista por Hume como parte de um plano, uma prudência política - uma “policy” visando a consolidação da autoridade do Conquistador. Do mesmo modo, as cartas assinadas por Henrique I: "ele nunca pensou em observar, durante o seu reino, nem um único de seus artigos (...), e a autoridade real (...) restava sem nenhuma forma de restrição"53.

O jugo normando teve como contraparte e se consolidou por meio da lei feudal, introduzida pelo Conquistador na Inglaterra:

Ele introduziu na Inglaterra a lei feudal, que se encontrava estabelecida da França e na Normandia, e que, naquela época, era o fundamento tanto da estabilidade quanto das desordens da maioria dos governos monárquicos da Europa. Ele dividiu todas as terras da Inglaterra, além dos domínios reais, com pouquíssimas exceções, em baronias; e as concedeu, sob a condição de determinados serviços e pagamentos, aos seus companheiros de guerra [adventures] mais consideráveis. Esses grandes barões, que sustentavam imediatamente a coroa, partilharam boa parte de suas terras com outros estrangeiros, denominados cavaleiros ou vassalos, que prestavam ao seu senhor os mesmos deveres de submissão na paz e na guerra que eles mesmos deviam ao seu soberano. A pequena parcela de ingleses que entrou nessa estrutura civil e militar (pois se tratava de ambas as coisas) estava tão restringida pela submissão aos estrangeiros que a dominação normanda pareceu agora se fixar sobre as mais duráveis bases e desafiar todos os esforços de seus inimigos. ${ }^{54}$

Assim, a lei feudal foi um sistema de apropriação e de distribuição da propriedade entre os normandos, ao mesmo tempo em que uma organização militar capaz de assegurar a conquista e o domínio normando sobre os ingleses. Ou seja, ela não apenas foi introduzida na Inglaterra pela força das armas, como consistiu num sistema de propriedade que garantiu e sustentou a dominação normanda. Ao acentuar o caráter violento e de dominação da conquista, Hume não está, contudo, aderindo à visão de que a lei feudal fosse desviante com relação à justiça e aos direitos fundamentais dos ingleses, como a via, por exemplo, Lord Kames, outro importante historiador da lei, seu contemporâneo e conterrâneo. ${ }^{55}$

Aqui, como na maneira de lidar com o topos da liberdade germânica, ele não adere ao lugar comum do jugo normando senão para alterar o seu significado comum no debate constitucional. Ainda que violenta, a lei feudal introduzida pela conquista é vista por Hume em seu caráter positivo, como uma etapa necessária (e não

\footnotetext{
53 Idem, p.253.
}

54 Idem, pp.203-4.

55 Assim, por exemplo, acerca da lei segundo a qual uma baronia não pode ser dividida em partes, Kames observa que esta, como muitos outros aspectos da lei feudal, é uma "concepção repugnante as ideias mais claras [plain] e naturais" (KAMES, H. H. Essays upon several subjects concerning British antiquities. London: M. Cooper, 1749, p.77), às quais felizmente se retornou, quando a sociedade feudal deu lugar à sociedade comercial. 
meramente acidental e dispensável, algo a se afastar $)^{56}$ na história da lei. Tratou-se, segundo ele, de uma "prodigiosa estrutura que,por diversos séculos, preservou uma tal composição de liberdade e opressão, ordem e anarquia, estabilidade e revolução, jamais experimentada em nenhuma outra parte do mundo" 57 . A lei feudal não foi, portanto, apenas um instrumento de dominação. Ela produziu ao mesmo tempo liberdade, ordem e estabilidade.

Sua importância na consolidação da lei inglesa está, em primeiro lugar, em ter ela fortalecido a autoridade legal do rei. Essa autoridade esteve fundada no período subsequente à conquista pela necessidade de manter a postura militar, de modo a assegurar os privilégios da nobreza normanda contra as revoltas e sedições. Mas, essa fonte de autoridade os reis foram perdendo aos poucos, conforme a lei feudal (que tem um caráter dinâmico, como veremos) foi aumentando o poder militar dos barões e diminuindo o do rei, e a autoridade do rei teria sucumbido ao poder dos barões, se não fosse, além de militar, uma autoridade legal - legislativa e judiciária. o Conquistador trouxe a administração da justiça para as mãos do soberano (o que na França só ocorreu dois séculos mais tarde).

A autoridade legislativa ele a partilhava com um conselho de nobres, os quais, de acordo com a lei feudal, além dos deveres militares, deviam ainda prestar certos serviços civis, como a participação nesses conselhos deliberativos, sob a convocação do rei. Isto, que era inicialmente visto como um fardo (um ponto sobre o qual Hume insiste, seguindo Brady), lhes interessava, na medida em lhes rendia alguma segurança contra o poder arbitrário do rei. Este, por sua vez, garantia com isso a concorrência no governo por parte dos nobres, os únicos com poder de the fazer oposição ${ }^{58}$. "O poder legislativo supremo da Inglaterra estava alojado no rei e grande conselho, ou o que depois se denominou o parlamento" ${ }^{59}$. Ou seja, foi a lei feudal, na relação de dependência e oposição que estabeleceu entre o rei e os barões, o que deu a Inglaterra o seu parlamento - um modo de compreender a gênese do parlamento

56 É como Kames entende a lei feudal: como o produto de circunstâncias determinadas que devem ser depuradas da história para que o que há de fundamental na lei possa aparecer. Aqui reside a diferença entre os dois historiadores da lei. Kames não quer mostrar, como faz Hume na História da Inglaterra, o modo como a lei se forma nas ou a partir das circunstâncias históricas. As circunstâncias sociais e históricas explicam, antes, para Kames, as imperfeições da lei. Assim, por exemplo, nos Historical Law-Tracts, Kames explica porque a propriedade não era considerada originalmente um direito pessoal estável pelo fato de que esteve, de início, associada aos bens móveis e, só depois, com o desenvolvimento da agricultura, foi ligada à terra, de modo que esta circunstância ocultou sua natureza - a de um direito pessoal estável - tal como esta natureza se deixou revelar com o tempo, gradualmente, na história. Trata-se assim, para Kames, de depurar a história das circunstâncias que encobrem o que há de fundamental no direito de propriedade.0 mesmo procedimento de depuração das circunstâncias observa-se nos Essays upon several subjects concerning British antiquities com relação às instituições feudais, que, de acordo com Kames, desnaturalizaram a lei.

57 H,I, pp.455-6.

58 Idem, p.471.

59 Idem, p.466. 
que permite a Hume explicar porque a hipótese contrária - a de que os conselhos deliberativos feudais abrigavam os comuns desde os tempos imemoriais - não apenas contraria os registros e documentos históricos, como mostraram Spelman e Brady, como é insustentável do ponto de vista da lógica política:

A única razão para instituir estes conselhos públicos, da parte dos súditos, era que desejavam alguma segurança contra as investidas de um poder arbitrário, e da parte do soberano, era que não podia governar homens com um tal espírito independente sem seu consentimento e concorrência. Mas os comuns, os habitantes dos burgos, não tinham atingido um tal grau de importância [consideration] a ponto de desejarem segurança contra seu príncipe ou para imaginar que, se reunidos num corpo representativo, teriam poder ou distinção [rank] o suficiente para forçá-la [to enforce it]. (...) Os sub-vassalos militares não podiam considerar a ideia de se opor ao seu príncipe e seus superiores. Menos ainda podiam os burgueses e comerciantes ter um tal pensamento. E assim, mesmo se a história silenciasse sobre isso, temos razões para concluir, a partir do que se sabe da situação das sociedades nessa época, que os comuns não eram jamais admitidos como membros do corpo legislativo. ${ }^{60}$

Mas, o que dava ao rei uma autoridade independente e suplementar era, à parte a autoridade administrativa e militar, que partilhava com os barões, a autoridade judiciária: "todo o poder judicial estava em última instância em suas mãos e era exercido por oficiais e ministros apontados por ele"61. Trata-se aqui das cortes judiciárias saxãs que continuaram em funcionamento após a conquista: “nenhum dos governos da Europa tinham instituições tais como as cortes municipais, que a grande autoridade do Conquistador reteve dos costumes saxões" ${ }^{62}$. Assim, as práticas judiciárias saxãs, tendo sido mantidas pelo Conquistador, passaram a ser sustentadas por sua autoridade - uma diferença importante com relação ao período saxão, quando os reis careciam de autoridade e as cortes de regularidade. O Conquistador soube se aproveitar dessas cortes em funcionamento como uma forma de impor e incrementar sua autoridade:

todos os senhores feudais, mesmo os grandes barões, eram obrigados a atender aos xerifes nessas cortes, e assisti-los na administração da justiça. Desse modo, eles eram sensível e frequentemente lembrados de sua dependência em relação ao rei ou supremo magistrado ${ }^{63}$.

Isso indica que não se tratou apenas de preservar as práticas legais saxãs, mas de transformá-las significativamente. Com efeito, Hume diz que, sob o governo do Conquistador, "a lei se tornou uma ciência", que "requeria muito estudo e aplicação"64.

Assim, juntamente com a unificação das cortes sob a autoridade do rei e com o

60 Idem, p.471.

61 Idem, p.472.

62 Idem, ibidem, nota Q.

63 Idem, ibidem.

64 Idem, p.473. 
aumento das transações que passavam por suas jurisdições, a magistratura passou a ser uma especialidade ou competência, aplicada por uma classe especial de homens, designados pelo rei - um modo de dizer que a lei aplicada nas cortes judiciárias deixou de ser, como entre os saxões, o costume e a lei natural, com sua ampla latitude de interpretação. A ciência envolvida na aplicação da lei consiste em analogias e regras de aplicação cujo efeito é a diminuição do poder discricionário dos magistrados e a regulação da lei - uma contribuição normanda fundamental, que faz da lei feudal um passo decisivamente positivo na consolidação do sistema legal inglês.

Outra contribuição decisiva foi a introdução da ideia de propriedade:

a ligação que naturalmente se formou com uma porção fixa de terra gradualmente produz a ideia de algo como a propriedade e faz com que o possessor esqueça sua situação de dependência e a condição originariamente anexada à concessão ${ }^{65}$.

Com o tempo, conforme se estreitaram os vínculos dos senhores feudais com o feudo, ele deixou de ser visto como o pagamento de um serviço militar e uma concessão do rei, e os barões passaram a demandar certos direitos de propriedade, certas garantias de uso continuado da terra e de hereditariedade. "A ideia de propriedade se introduziu gradualmente sobre a do pagamento militar, e cada século trouxe algum acréscimo sensível à estabilidade dos feudos e dos títulos de posse". ${ }^{66}$

Que a posse continuada leve à propriedade é, como sabem os leitores do Tratado da Natureza Humana, uma lei natural - ou, se quisermos: uma regra geral da História. Toda sociedade passa pelo processo que conduz da posse ao direito de posse. Hume está propondo que esse processo foi posto em marcha na Inglaterra pela lei feudal, na medida em que sua estrutura militar foi uma circunstância de estabilização da posse, que, por sua vez, é a condição para que se chegue à ideia de direito de posse ou propriedade. Não é pequena, portanto, a contribuição da lei feudal para a constituição do direito inglês: deve-se a ela a noção de um direito de propriedade.

Mas sua importância não se esgota aí. Hume aprendeu com Harrington que as instituições feudais (para Harrington: saxãs e normandas indistintamente) não eram estáticas, mas possuíam uma dinâmica interna relacionada ao modo de circulação da propriedade. Harrington mostrou que às monarquias góticas correspondia uma certa balança da propriedade, um certo modo de distribuição da propriedade, segundo o qual a terra estava concentrada nas mãos de uma aristocracia, que dava sustentação (entenda-se: força militar) à monarquia. Quando essa balança se altera, quando o povo passa a ser proprietário, a monarquia acaba tendo que necessariamente dar lugar a um governo de tipo republicano.

65 Idem, p.458.

66 Idem, Ibidem. 
Hume entende que uma certa dinâmica da propriedade não apenas foi responsável pela superação das instituições feudais e a ascensão dos comuns, como também pelas transformações internas das próprias instituições feudais, perpassadas por uma tensão permanente entre a autoridade do rei e o poder dos barões. Segundo ele, a estabilização da propriedade nas mãos dos barões resultou em poder para os mesmos (uma lição de Harrington). Um poder que, fortalecido pelas relações de dependência entre o senhor feudal e seus vassalos e pela ideia de propriedade, passou a rivalizar com o do rei. Hume entende que foi esse processo que levou à rebelião dos barões contra o rei João, cuja autoridade fraca e violenta, incapaz de proteger os ingleses das forças externas, como a monarquia francesa e o papado, assim como de fazer frente à força crescente de sua aristocracia, ofereceu a ocasião para que se produzisse o que segundo Coke foi a "lei das leis" da Inglaterra: a Magna Carta. De acordo com Hume, foi o jogo de forças entre os barões e o rei, intrínseco à lei feudal, o que conduziu ao acordo celebrizado no documento assinado no século XIII pelo rei João e os barões e reafirmado no início do reino de Henrique III, seu sucessor (é a carta de Henrique III que ficou conhecida ${ }^{67}$ ). Este documento, "estimado como o mais sagrado baluarte da liberdade e da independência nacional"68, marcou, segundo Hume, o começo de um novo tempo - o de uma monarquia limitada por um estatuto positivo.

\section{A Magna Carta}

Hume dá enorme importância a Magna Carta e, como nos casos da liberdade saxã e da conquista normanda, não se opõe frontalmente aos mitos a seu respeito, mas os reinterpreta. Não apenas ele aceita a ideia de que a Magna Carta possa ter sido a confirmação das leis de Eduardo, o Confessor ${ }^{69}$ - ainda que pondere que isso não passe de uma conjectura, já que não restam registros das leis de Eduardo que o comprovem - como afirma que ela confirma as leis saxãs justamente naquelas cláusulas pelas quais os interesses gerais, e não apenas o dos barões, foram contemplados ${ }^{70}$. A Magna Carta "concedeu ou assegurou liberdades e privilégios importantes para toda as ordens de homens no reino: ao clero, aos barões, ao povo"71. Não serviu, portanto, apenas aos interesses dos barões, embora estes estivessem contemplados de maneira principal. Mas, se atendesse apenas aos barões, pondera Hume, “a felicidade nacional

67 Cf. THOMPSON, F. Magna Carta, its role in the making of the English constitution (1300-1629). Minneapolis: The University of Minnesota Press, 1948, p.5. Sobre pequenas diferenças entre as cartas de João e de Henrique, ver H, II, pp.5-6.

$68 \mathrm{H}, \mathrm{II}, \mathrm{p} .6$.

69 Cf., H, I, nota J, p.493.

70 Idem, p.446.

71 Idem, p.443. 
e a liberdade teriam sido muito pouco promovidas por ela"72. E Hume entende que a Magna Carta efetivamente promoveu a liberdade, aderindo assim à ideia de Coke segundo a qual a Magna Carta é a Carta das liberdades inglesas. Tratou-se, segundo Hume, de "um tipo de contrato original, que limitou a autoridade do rei ao mesmo tempo em que garantiu a submissão condicional de seus súditos"73.

Mas, dizer que a Magna Carta promoveu liberdade é bem diferente de dizer que ela é a confirmação de liberdades prévias, como queria Coke. Hume não está aderindo à visão dominante no debate constitucional, na raiz da qual estão os comentários de Coke a Magna Carta ${ }^{74}$, segundo a qual esta seria uma das mais importantes confirmações da lei fundamental inglesa. Enquanto a primeira constituição escrita da Inglaterra, a Magna Carta é para Hume a causa, não um efeito, da liberdade inglesa.

Hume distingue entre as cláusulas da Carta que atendiam aos interesses dos barões em particular - como por exemplo a suspensão de certos serviços militares ${ }^{75}$ - das cláusulas que respondiam ao interesse geral, como que todos podem sair e voltar do reino segundo sua vontade e gozar livremente dos seus bens, que as cortes de justiça estão abertas a todos, que ninguém pode ser aprisionado sem julgamento prévio, que todos devem ser multados de maneira proporcional a sua falta e de maneira a que não venha a ser arruinado. A distinção entre as duas categorias de cláusulas é importante porque mostra que, se foi o interesse particular dos barões e não o interesse geral o que produziu a Magna Carta, ela teve como um efeito não calculado a promoção do interesse geral: "todas as medidas que os barões em benefício próprio foram obrigados a tomar a fim de assegurar uma administração livre e equitativa da justiça, tendiam diretamente ao benefício de toda a comunidade" $"$.

Isso está em perfeito acordo com e ilustra bem o que Hume diz no Tratado III. 2. 1. Neste texto bastante comentado e visitado, Hume argumenta que, diferentemente das virtudes naturais, não há, no caso da justiça, um motivo original que nos leve a agir justamente, ou seja, a respeitar regras de justiça, o que nos coloca diante de uma dificuldade, uma vez que, segundo as premissas da ética humiana (nesse ponto herdeiro de Shaftesbury), para que haja valores morais, para que se possa falar em "virtudes" e "vícios", é preciso haver determinadas motivações originais que, tendo sido julgadas boas ou más, passam a valer como virtudes ou vícios. Mas não parece haver uma tendência natural para a justiça, distinta do senso de dever e da obrigação de ser justo. Como então explicar esse senso de dever? Como a justiça pode ser uma virtude, se não há uma motivação original para a justiça a ser julgada

72 Idem, p.444.

$73 \mathrm{H}, \mathrm{II}, \mathrm{p} .7$.

$74 \mathrm{Cf}$. COKE, E. The second part of the Institutes of the law of England. London: Brooke, 1797.

$75 \mathrm{H}, \mathrm{I}, \mathrm{p} .443$.

76 Idem, p.444. 
virtuosa? A resposta de Hume para o problema consiste em dizer que a justiça é uma virtude artificial.

A motivação para ser justo nasce da convenção, do acordo em torno de uma regra de cooperação ${ }^{77}$. Esta regra altera a direção do interesse em cooperar, transformando o que inicialmente era um interesse próprio num interesse comum, que é o interesse pelo esquema de cooperação. Quem faz essa passagem é a convenção. Ela redireciona o interesse. Assim, é por interesse próprio que somos levados a instituir um esquema de cooperação; uma vez instituído este esquema, passamos a ter um interesse comum nele. Essa motivação (a consideração pela utilidade comum da justiça) é o que é levado em consideração quando a justiça é considerada uma virtude $^{78}$. Não se trata de uma motivação original no homem, mas de uma motivação que se forma pelo redirecionamento do interesse privado em interesse público por intermédio da convenção, quando esta se apresenta como o objeto de um interesse comum.

Hume não está falando nessas passagens do Tratado especificamente da convenção envolvida na criação da lei positiva, mas de todo tipo de acordos de cooperação, dos quais o acordo em torno da lei positiva é um caso. Mas a lei positiva é certamente o mais importante esquema de cooperação e a mais eficiente regra de propriedade. Ela é, como se vê pelo papel atribuído por Hume a Magna Carta, uma instituição decisiva na formação de um senso comum de justiça, que nada mais é do que um interesse comum na manutenção de certos esquemas de cooperação - no caso, a lei escrita. Hume mostra como a Magna Carta, tendo sido produzida pelo interesse particular dos barões, se tornou o objeto de um interesse comum.

Em suas cláusulas mais gerais a Carta contém, segundo ele, "as linhas mestras de um governo legal”. Ela promoveu "uma distribuição igual da justiça” e "o livre gozo da propriedade"79 - "os grandes objetos em vista dos quais toda sociedade política foi primeiramente fundada pelos homens" ${ }^{80}$. Hume acrescenta ainda que

77 Cf. HUME, D. Essays Moral, Political and Literary, p.483

78 Cf. HUME, D. Enquiries concernig the principles of morals. Selby-Bigge (ed.). Oxford: Clarendon Press, 1975, seção III.

79 Trata-se aqui da equidade (a distribuição igual da justiça) e da justiça (o livre gozo da propriedade). Como nota A. Bayer (BAIER, A. The cautious jealous virtue: Hume on justice, cap. 6), Hume está concernido com a questão da equidade, que não é para ele o mesmo que a justiça, mas que está em relação com ela. Segundo Bayer, a equidade é uma virtude natural (uma tendência para a "distribuição igual", naturalmente presente na mãe com relação aos filhos) que se enlaça à virtude artificial da justiça (à motivação para adotar esquemas de cooperação e seguir regras de justiça) e se torna uma motivação para aplicar essas regras de maneira igual. Não estou certa de que a equidade seja para Hume uma virtude natural e que ela possa ser pensada separadamente da justiça e da convenção que ela envolve. Seja como for, penso que, da perspectiva de Hume, a equidade só está concernida na justiça a partir do momento em que a lei positiva desponta como o objeto de um interesse comum. A partir daí ganha sentido a questão de saber qual é a parte que cabe a cada um na distribuição dos direitos pela lei, que é a questão da equidade.

$80 \mathrm{H}, \mathrm{l}, \mathrm{p} .445$. 
reivindicar esses objetos é um "direito perpétuo e inalienável do povo" 1 , resvalando assim na linguagem dos direitos fundamentais e sugerindo que a Carta os assegura. Nem por isso ele está aceitando a ideia de que tais direitos precedam a instituição da lei e que existam antes dela para serem confirmados. 0 que existe antes da lei não são propriamente direitos, mas interesses perpétuos e inalienáveis, que operam como uma causa geral no processo histórico de instituição de direitos. Esse interesse se fará valer e atuará em toda sociedade como uma causa da lei. Vale lembrar, no entanto, que ele não atua sozinho e nem como primeira força motriz - foi o interesse particular dos barões, somado às circunstâncias particulares que thes garantiram o poder de fazer valer seus interesses, o que levou ao acordo em torno da Magna Carta. Mas o caráter geral de alguns de seus princípios fez com que a Carta atendesse a interesses mais gerais e regulares, fazendo-se objeto de um interesse comum.

Hume mostra no volume II da História da Inglaterra como a Carta se tornou um documento ao qual as diversas ordens da sociedade puderam recorrer a fim de assegurar, conquistar, produzir direitos - os nobres recorrem a ela contra o rei ${ }^{82}$, o rei contra os nobres ${ }^{83}$, e, mais importante ainda, os comuns, os habitantes dos burgos que começavam a se fazer representar no Parlamento, recorreram a Carta contra o rei $^{84}$ e os barões ${ }^{85}$.

A Carta, é verdade, não foi capaz de se contrapor ao poder dos barões, cujas desordens e ultrajes ocupam a maior parte da narrativa do volume II, sendo a marca do período que se estende da proclamação da Carta à consolidação da autoridade real, com os Tudor. Tampouco foi muito respeitada. Ao contrário, Hume assinala as inúmeras ocasiões em que ela foi violada por parte do rei e dos barões ${ }^{86}$. Sobre as repetidas confirmações da Carta por Eduardo III, escreve que

essas concessões são normalmente tomadas como provas de sua grande indulgência para com o povo e de sua cuidadosa consideração por suas liberdades. Mas a pressuposição contrária é mais natural. (...) Com efeito, foi uma consequência do governo irregular dessas épocas que um estatuto, decretado há alguns anos, em vez de adquirir, era percebido como tendo perdido força com o tempo, e precisasse ser frequentemente restabelecido por estatutos recentes do mesmo teor e sentido [sense]. ${ }^{87}$

Ainda assim, muito embora "as práticas arbitrárias frequentemente prevalecessem", sob Eduardo I, a Magna Carta estava "finalmente estabelecida", no sentido que, dali para frente, sua validade "não esteve mais formalmente em

81 Idem, ibidem.

82 Cf. H, II, p.119-20.

83 Cf. Idem, p.163.

84 Cf. Idem, p. 277.

$85 \mathrm{Cf}$, Idem, p.287.

86 Por exemplo, Idem, pp.29;31;142;215.

87 Idem, p. 275. 
disputa" 88 . Isso quer diz que a Carta se consolidou como um estatuto ao qual as diversas ordens podiam e de fato recorriam a fim de reivindicar direitos. Particularmente importante é o modo como os comuns o fizeram, num movimento que, de acordo com Hume, levou ao fim da lei feudal e ao despertar, ainda que tímido, do governo popular na Inglaterra.

A ascensão dos Comuns ao longo dos séculos XIV e XV é o mais importante tema do volume II da História da Inglaterra. Ali, Hume mostra como a formação da casa dos comuns no parlamento se deu em função de uma série de causas sociais.

Novas situações produziram novas leis e instituições: e as grandes alterações nas finanças e no poder militar da coroa, tanto quanto na propriedade privada, foram a fonte de iguais inovações em toda parte da legislatura [legislature] ou governo civil. ${ }^{89}$

Hume está se referindo à necessidade que os reis passaram a ter de barganhar com o parlamento os montantes necessários para cobrir os gastos das guerras contra a França e a Escócia (sendo a guerra externa, segundo Hume, um elemento importantíssimo na sustentação da autoridade do rei e na pacificação das lutas de facção entre os barões). Em virtude da transformação da lei feudal e da oposição crescente entre os barões e o rei, a coroa já não era mais capaz de reunir um exército em torno de si, a não ser em troca de pagamento. Diante de barões cada vez mais arredios e exigentes, os reis passaram a adotar a "salutar política [policy]" de convocar os representantes dos burgos ao parlamento, uma industriosa classe de homens que, não apenas não tinha força para se opor ao rei, como tinha interesse em suportar a coroa e a lei contra a opressão dos barões, de modo que esta foi uma maneira de conseguir o seu consentimento para a taxação das mercadorias produzidas e comerciadas por ela90. Junte-se a isso as mudanças apontadas por Harrington na balança da propriedade pela subdivisão das baronias, levando à formação de uma classe de barões menores, que também "encontraram proteção legal à sombra do trono" 91 e cuja amizade o rei cortejava como uma maneira de enfrentar a poder dos barões maiores. O que se segue é uma nova correlação de forças, que conduziu à gradual formação da casa dos comuns como uma câmara separada do Parlamento.

O que importa notar é que o processo de ascensão social e política dos comuns é contemporâneo do processo de consolidação da Magna Carta, sendo difícil definir nesse processo o que veio primeiro, se as mudanças sociais ou legais. Se o novo jogo das forças sociais sustentou a autoridade formal da Carta (bem como de outros estatutos positivos do período), na medida em que ela servia aos interesses dos comuns, em ascensão, a Carta criou as condições legais (a proteção das atividades

88 Idem, p.122.

89 Idem, p.101.

90 Cf. H, II, p.105.

$91 \mathrm{H}, \mathrm{II}, \mathrm{p} .104$. 
comerciais) sem a qual essa ascensão não teria sido possível.

\section{Conclusão}

Recuemos, porém, ao volume I da História da Inglaterra e à pré-história da lei. 0 que se percebe, pelo modo como Hume interpreta os eventos da história medieval da Inglaterra, ao pensá-los como parte de um processo de instituição da lei, é que ele se opõe sistematicamente a uma interpretação dos eventos chave dessa história de modo a que se decantem o domínio da lei (razão) e o da violência (fato). Ele recusa à lei uma origem sacrossanta. É isso o que significa dizer que a lei é integralmente histórica. É dizer que, não estando dada no plano da razão para ser de algum modo reconhecida e sedimentada nos costumes, ela se constitui a partir de certas circunstâncias sociais, do modo como a vida humana se organiza, dos costumes, mas também das relações de propriedade e poder (segundo o sentido que Harrington dá ao termo e em que pensa a relação entre eles). Hume procura mostrar no volume I da História da Inglaterra que tais relações são o que respondem pelas instituições saxãs, o que esteve no centro da Conquista Normanda e de seu legado, a lei feudal, e é o que explica a instituição e consolidação da autoridade da lei positiva como elemento de regulação e transformação social. Assim, se o papel da lei é o de regular e racionalizar a violência, ela se desenvolve (e não está dada no plano da razão) a partir dos jogos de força, os quais cabe ao historiador captar e descrever, mostrando assim a origem social da lei ou a inscrição da normatividade jurídica no fato social a partir do qual ela se desenvolve.

\section{Referências}

BAIER, A. The cautious jealous virtue: Hume on justice. Cambridge/ London: Harvard University Press, 2010.

BRADY, R. An historical treatise of cities and burghs or boroughs. London: Browne, 1711 (re-print Gale ECCO print editions).

BUCKLE, S. Natural Law and the Theory of Property. Grotius to Hume. Oxford: Clarendon Press, 1991.

COKE, E. The second part of the Institutes of the law of England. London: Brooke, 1797 (re-print ULAN press).

GIARRIZZO, G. David Hume politico e storico. Torino: Einaudi, 1962.

GOUGH, J. W. Fundamental Law in the English Constitutional History. Oxford: Oxford University Press, 1955. Tradução francesa: Paris: PUF, 1992.

HAAKONSSEN, K. The science of a legislator: the natural jurisprudence of David Hume and Adam Smith. Cambridge: Cambridge University Press, 1981.

HUME, D. Enquiries concernig the principles of morals. Selby-Bigge (ed.). Oxford: Clarendon Press, 1975. 
. The History of England, 6 vols. Indianapolis: Liberty Fund, 1983.

. Essays Moral, Political and Literary. Miller, E. (ed.). Indianapolis:

Liberty Fund, 1985.

A Treatise on Human Nature. Selby-Bigge/ Nidditch (eds). Oxford: Clarendon Press, 1989.

MCARTHUR,N. David Hume's political theory, law, commerce, and the constitution of government. Toronto: University of Toronto Press, 2007.

PIMENTA, P.P. A imaginação crítica, Hume no século das Luzes. Rio de Janeiro: Azougue, 2013.

POCOCK. J. G. A. The ancient constitution and the feudal law. New York: Norton library, 1967.

\section{9.}

KAMES, H. H. Essays upon several subjects concerning British antiquities. London: M. Cooper, 1749 (Nabu Public Domain Reprints).

- Historical Law-tracts. Edinburgh: A. Kincaid, 1761 (The lawbook exchange, Ltd. Union, New Jersey, 2000).

SMITH, R. J. The gothic bequest, medieval institutions in British thought, 16881863. Cambridge: Cambridge University Press, 1987.

THOMPSON, F. Magna Carta, its role in the making of the English constitution (13001629). Minneapolis: The University of Minnesota Press, 1948.

WALDRON, J. A Dignidade da Legislação. São Paulo: Martins Fontes, 2003.

WEIN, S. David Hume and the empiricist theory of law. Man and Nature, 9, 1990, pp.33-44 (reeditado em Mackinnon, K. Hume and Law, Ashgate, 2012, pp.23-34) WESTON, C. C. “L'Anglaterre: l'ancienne constitution et le droit commun”, In: Burns, J. H. (org.) Histoire de la pensée politique moderne, 1450-1700. Paris, PUF, 1997. 